\title{
Kearifan Ekosistem Budaya pada Tata Ruang Lanskap Budaya Jawa Kuno di DAS Kali Brantas
}

\author{
The Wisdom of Cultural Landscape in the Ancient Javanese \\ Landscape at Kali Brantas Basin
}

\section{Chairul Maulidi, Johannes Parlindungan Siregar}

Diterima: 20 Januari 2020 Disetujui: 6 Mei 2020

\begin{abstract}
Abstrak: Gagasan mengenai perlindungan budaya, kelestarian alam, potensi karya estetika saat ini disadari oleh masyarakat dunia sebagai bagian dari pembangunan yang berkelanjutan. Tatanan lanskap budaya dicirikan oleh norma tradisional masyarakat dan fisik peradaban yang terbentuk dalam kearifan lokal dalam menggagas penataan lingkungan lanskap dan arsitektur tradisional. Penelitian ini bertujuan untuk merekonstruksi hubungan antara karakter geografis dengan pola pemanfaatan ruang lanskap sebagai bagian dari budaya lokal di masa peradaban Jawa kuno (abad ke-9 sampai dengan 15) di wilayah DAS Brantas. Kajian ini menghasilkan bentuk penerapan kosmologi jawa pada skala ruang wilayah. Menurut karakter pemanfaataan ruang dan materi fisik dan sosialnya, ruang wilayah Jawa kuno terdiri atas tiga zona, yaitu Zona Bawah, Zona Tengah dan Zona Atas. Temuan ini dapat menjadi model kearifan lokal dalam tata ruang kewilayahan, sebagai sandingan bagi konsep modern pembangunan kota yang memandang seluruh bentang lanskap sebagai aset kapital
\end{abstract}

Keyword in Indonesian: Brantas, lanskap budaya, Jawa kuno

\begin{abstract}
The protections for culture, natural environment and aesthetic are widely recognised as a part of sustainability. The cultural landscape were characterised by the traditional norms of the society and physical civilisation manifested in local wisdoms creating the traditional landscape and architecture. This study aimed to reconstruct the use of landscape as part of local culture representing the ancient Javanese civilization (9th to 15th century) in the Brantas River Basin. This study found how the Javanese cosmology was applied on a regional scale of space. According to the character of spatial use as well as its physical and social materials, the space of the ancient Javanese region consisted of three zones, namely: the Lower, Central and the Upper Zones. This findings was a model of local wisdom in the regional scale, as a counterpart of the contemporary notion of urban development that conceives the lanscape as a capital asset.
\end{abstract}

Keywords: ancient Java, Brantas, cultural landscape

\section{PENDAHULUAN}

Pola tata ruang lanskap budaya adalah produk dari interaksi jangka panjang antara manusia dan alam di suatu wilayah serta merupakan bagian penting dari warisan sejarah (Atik \& Erdoğan, 2017). Tatanan lanskap budaya tersusun atas jalinan norma tradisional kehidupan sehari-hari masyarakat yang terbentuk sebagai wujud kebijaksanaan dan kemampuan kreatif leluhur dalam lingkungan lanskap dan arsitektur tradisional (Setijanti et al., 2015). Meskipun terkait erat dengan gaya hidup tradisional, lanskap budaya juga mengandung nilai-nilai yang relevan dalam masyarakat kontemporer (Church, Fish, Ravenscroft, \& Stapleton, 2015), karena ia sejalan dengan gagasan perlindungan budaya, 
kelestarian alam dan pengembangan ekonomi (Giannakopoulou, Xypolitakou, Damigos, \& Kaliampakos, 2017; Radzuan, Fukami, \& Ahmad, 2015). Penelitian ini adalah kelanjutan dari dua penelitian terdahulu. Penelitian pertama, berjudul "Konstruksi Lokalitas Tatatan Lanskap Budaya Jawa kuno dari Relief Candi di Jawa Timur" mengilustrasikan fitur fisik yang ada di setiap tipe lingkungan (Maulidi \& Rukmi, 2018b). Penelitian kedua, berjudul "Tatanan Spasial lanskap Jawa di Lembah Kali Brantas dari data Arkeologis" membuktikan bahwa ada hubungan antara lokasi setiap tipe lanskap dengan elevasi geografis dari lanskap (Maulidi \& Rukmi, 2018a).

Bentang Lanskap budaya Jawa kuno yang berasal dari periode Hindu-Budha di Jawa Timur terbangun dari berbagai aspek kehidupan yang terjalin dalam bentuk sistem yang harmonis (Rahardjo, 2011). Peradaban yang tumbuh antara abad ke-8 hingga ke-15 ini ditandai dengan dominasi pengaruh peradaban India. Konfigurasi ruang meso dan mikro, seperti tata letak bangunan di satu komplek percandian dan permukiman kental dengan penerapan prinsip-prinsip Vastu Shastra. Vastu Shastra adalah ilmu penataan ruang, massa dan bentuk untuk memberikan sentuhan yang adil dalam setiap aspek kehidupan di bumi serta alam semesta (Kramrisch, 1981), dalam mencapai keselarasan antara alam dan manusia di lingkungan hidup (Kumar, 2005).

Proses memadukan ilmu pengetahuan dan karakter alam setempat dalam bentuk praktik berulang, kemudian menciptakan kapabilitas individu atau kelompok dalam menempatkan diri pada lanskap alami demi mencapai kemakmuran. Kapabilitas seperti tersebut kemudian diterjemahkan sebagai 'kearifan lokal' (Fish, Chruch, \& Winter, 2016). Hubungan dialektis antara lingkungan (lanskap alam) dengan praktik kebudayaan menjadi pondasi bagi konsep Jasa Ekosistem Budaya atau Cultural Ecosystem Services (CES). Konsep ini merupakan pendekatan operasional untuk mengintegrasikan berbagai kontribusi alam dan budaya, yang kemudian diaplikasikan ke dalam proses pengambilan keputusan perencanaan dan pembangunan kota (Chan, Satterfield, \& Goldstein, 2012; Costanza et al., 2017). Motivasi budaya dalam pembangunan adakalanya memiliki pengaruh yang lebih besar daripada motif produksi komoditas (Plieninger \& Bieling, 2012). Pendekatan CES juga dipergunakan sebagai referensi untuk memahami manfaat nonmaterial yang diperoleh dari suatu ekosistem, seperti manfaat rekreatif, budaya, sosial, ekonomi, dan spiritual (Costanza et al., 2017). Kategori CES berkembang dan meluas menjadi kerangka kerja nilai spiritual dan agama, rekreasi dan ekowisata, inspiratif, rasa tempat, warisan budaya dan layanan pendidikan bagi masyarakat.

Berdasarkan tinjauan di atas, kemungkinan pada tatanan lanskap Jawa kuno di Malang Raya terdapat model penataan ruang yang berkelanjutan yang dapat diangkat kembali sebagai pembanding teori tata ruang kota kontemporer. Dengan demkian, maka penelitian ini dilakukan untuk menggali keterkaitan antara karakter lanskap alami dan pola pemanfaatan ruang pada peradaban Jawa kuno di Lembah Kali Brantas pada masa pembentukan lanskap budaya tersebut. Penelitian ini menggunakan pendekatan CES, yakni dengan melihat bagaimana pola lanskap kota Jawa kuno memberikan manfaat kepada masyarakat pada masa itu kemudian merumuskan wujud kearifan lokal tata ruang lanskap kota Jawa kuno yang dapat menjadi referensi alternatif bagi model penataan ruang yang berkelanjutan sekaligus sebagai identitas kota-kota di Jawa.

\section{METODE}

Penelitian ini ditujukan bertujuan untuk menemukan hubungan antara karakter lanskap alami dan praktik pemanfaatan ruang lanskap wilayah DAS Kali Brantas di periode abad ke 9-15 masehi; bagaimana cultural ecosystem services tatanan lanskap Jawa kuno saat itu; dan bagaimana kearifan lokal dari tatanan ruang kanskap wilayah dan kota Jawa kuno dalam mengharmoniskan manusia dan alam. 
Pendekatan penelitian yang dipergunakan adalah merekonstruksi aktivitas penggunaan ruang pada bentang lanskap DAS Kali Brantas di masa Jawa kuno dan menyusun keterhubungan antara budaya dan lingkungan sebagai satu kesatuan budaya lanskap. Data yang telah terkumpul diklasifikasikan menurut keserupaan konten secara kualitatif menggunakan perangkat lunak N-Vivo. Selanjutnya proses penjalinan informasi dielaborasi untuk menemukan keterhubungan lingkungan dan nilai budaya melalui proses brainstorming tim peneliti dengan sejarawan dan arkeolog. Penelitian ini dilakukan melalui beberapa tahap berikut:

1. Pengumpulan Data: data yang diperlukan adalah gambaran tentang aktivitas penggunaan ruang lanskap wilayah di DAS Kali Brantas pada masa Jawa kuno. Data tersebut dikumpulkan melalui penyuntingan informasi terkait dari dokumen dan buku hasil penelitian arkeolog dan ahli sejarah.

2. Pengolahan Data: data mengandung informasi tentang lokasi dan aktivitas. Seluruh data yang terkumpul kemudian dikelompokkan menurut kesamaan karakter aktivitas penggunaan ruang dan diberi label 'tipe' cultural ecosystem services, ragam tipe tempat seperti: estetis, ritual, relaksasi, profan, sakral, keramaian, dan sejenisnya yang dapat berkembang sesuai dengan karakter data.

3. Verifikasi data ke Lapangan: dilakukan oleh peneliti untuk memastikan karakter lanskap yang digambarkan dalam dokumen (data sekunder). Proses ini melalui survei lapangan ke lokasi site terpilih, mencatat dan mengambil gambar karakter fisik lanskap dan situs serta pemandangan lanskap di sekitarnya.

4. Brainstorming. proses untuk mengelaborasi data terolah dan didiskusikan dengan ahli sejarah, untuk mendapatkan pola hubungan yang lebih mendalam antara krakter fisik geografis dengan nila-nilai yang mendasari terjadinya aktivitas di ruang lanskap.

Lokasi penelitian adalah wilayah Lembah Kali Brantas di Provinsi Jawa Timur. Secara Administrasi meliputi wilayah Kabupaten Sidoarjo, Pasuruan, Malang, Batu, Blitar, Kediri, Jombang, Mojokerto, dan sebagian wilayah Kabupaten Tulungagung. Pemilihan lokasi wilayah penelitian dilatari oleh catatan sejarah yang menyebutkan peradaban Jawa kuno di periode Jawa Timur berkembang di wilayah DAS Kali Brantas ini.

\section{HASIL DAN PEMBAHASAN}

Sungai Brantas terletak di provinsi Jawa Timur, Indonesia. Sungai ini merupakan sungai terpanjang kedua di Pulau Jawa setelah Bengawan Solo. Sungai Brantas bermata air di Desa Sumber Brantas, Kecamatan Bumiaji, Kota Batu, yang berasal dari simpanan air Gunung Arjuno, lalu mengalir ke Malang, Blitar, Tulungagung, Kediri, Jombang, Mojokerto. Di Kabupaten Mojokerto sungai ini bercabang dua menjadi Kali Mas ke arah Kota Surabaya dan Kali Porong ke arah Kabupaten Sidoarjo. Sejak abad ke-8, DAS Kali Brantas telah menjadi lokasi peradaban manusia. Pada masa itu, beberapa kerajaan dengan corak agraris silih berganti dimulai dari masa kerajaan Kanjuruhan sebagai negara bawahan Mataram kuno yang berpusat di Jawa Tengah. Kerajaan ini meninggalkan Candi Badut dan prasasti Dinoyo yang berangka tahun $760 \mathrm{M}$ sebagai bukti keberadaannya.

\section{Budaya dan peradaban Jawa kuno}

Sumber-sumber prasasti menyebutkan pada masa pertengahan Abad ke-9, pendetapendeta Buddha datang ke Jawa dari wilayah India yang berbeda, yakni dari Benggala dan Gujarat (Casparis, 1956). Sebelum abad ke-13 dua agama tumbuh di Jawa bersama-sama dan dapat dikatakan menjadi dasar pembentukan peradaban Jawa awal.

Menurut Pott (1966), baik pada masa Jawa Tengah maupun pada masa Jawa Timur, Siwaisme dapat dikatakan tidak berbeda. Doktrin yang ditanamkan tetap sama, yakni 
ajaran keselamatan. Awalnya Buddha berkembang di Jawa dimulai dengan tahap Mahayana dan berkembang ke arah Tantrayana. Dalam Mahayana tujuan penganutnya adalah untuk mencapai ke-Budha-an, yang hanya dapat diperoleh melalui perjuangan berat dan dalam waktu yang lama. Sedangkan dalam Tantrayana tujuan yang sama dianggap dapat diperoleh dalam kehidupan sekarang juga, yakni melalui praktik yoga dengan memuja Buddha dan kepatuhan total kepada seorang guru.

Pertengahan Abad ke-9 menunjukkan perkembangan secara penuh dari berkembangnya agama ini di Jawa Timur, meskipun diakuinya juga bahwa ada unsurunsur tertentu yang biasanya dijumpai dalam aliran Tantrayana. Namun begitu terdapat kesepakatan umum bahwa baik agama Hindu maupun Buddha cenderung bersifat Tantra ketika memasuki periode Jawa Timur (Abad ke-10) yang tampak pada arca dan dalam teks-teks sastra. Pada masa itu juga di Jawa Timur kedua agama cenderung mengembangkan sistem pemikiran yang saling mempengaruhi satu sama lain. Khususnya tentang prinsip kebenaran tertinggi, sehingga muncul gejala yang pernah disebutnya sebagai sinkretisme, koalisi, atau pararelisme (Pott, 1966; Sedyawati, 1984). Pendeta memiliki peran menonjol dalam kehidupan keagamaan dan kerajaan. Peran yang cukup jelas bahwa dalam upacara-upacara tertentu, khususnya yang berkaitan dengan pendirian bangunan suci, raja-raja Jawa.

Selain makna dan fungsi pemujaan gunung di Jawa zaman klasik seperti yang diuraikan di atas, gunung memiliki berbagai makna simbolis dalam mitologi. Simbolisme mitologi gunung sangat terkait dengan simbolisme air. Air telah dan masih menjadi unsur penting dalam pertanian di Jawa. Khususnya dalam budidaya padi di sawah, berbagai prasasti membuktikan bahwa pada abad ke-9 sawah beririgasi sudah mapan di Jawa. Simbolisme air yang paling penting adalah air sebagai Amerta, cairan mistis keabadian dan air kehidupan. Beberapa mitos Jawa kuno menampilkan amerta sebagai barang berharga yang dijaga ketat para dewa. Pentingnya tema Mahameru-Amerta dalam mitologi Jawa timur diwujudkan dalam sejumlah besar candi dan obyek. Air mancur dari pemandian Jolotundo yang airnya keluar dari bentuk yang melambangkan Gunung Meru, adalah contoh yang menonjol dari simbolisme Amerta.

Dua karya kesustraan yang memiliki gambaran situasi dan kejadian di masa Jawa kuno adalah Kitab Pararaton dan Kitab Nagarakrtagama (Damaika, 2018). Pararaton (bahasa Kawi: "Kitab Raja-Raja") adalah sebuah kitab naskah Sastra Jawa Pertengahan yang digubah dalam bahasa Jawa Kawi. Isinya adalah sejarah raja-raja Singhasari dan Majapahit di Jawa Timur. Kitab ini juga dikenal dengan nama "Pustaka Raja", yang dalam bahasa Sanskerta juga berarti "kitab raja-raja". Tidak terdapat catatan yang menunjukkan siapa penulis Pararaton. Sedangkan kakawin ini, Nagarakretagama artinya adalah "Negara dengan Tradisi (Agama) yang suci". Nama Nagarakretagama itu sendiri tidak terdapat dalam kakawin Nagarakretagama. Nama Nagarakretagama tercantum pada kolofon terbitan Dr. J.L.A. Brandes: Iti Nagarakretagama Samapta.

\section{Ekosistem Budaya pada Beberapa Tipe Lingkungan}

Berdasarkan literatur sejarah dan arkeologis terdapat beberapa tipe lingkungan yang ditinggali pada masa Jawa kuno, antara lain: Kedatwan, Sima/ Wenua, Dharma Haji, Dharma Ipas dan Mandala (Rahardjo, 2011).

Kadatwan atau Kedaton adalah ibukota tempat tinggal raja, keluarga bangsawan, pasukan kerajaan, dan juga pemimpin keagamaan. Oleh karenanya lingkungan Kadatwan sangat kompleks dalam hal ragam peninggalan situs. Kawasan ini paling banyak dijumpai pada kawasan situs Trowulan bekas ibukota Majapahit, di mana ditemukan gapura, pagar dan kanal, reruntuhan permukiman dan peralatan rumah tangga, beragam jenis candi, kolam dan petirtaan. Keterangan mengenai susunan fisik ibukota atau istana dapat 
diketahui berdasarkan berita Cina, karya sastra dan data arkeologi. Keterangan tertua mengenai ibukota kerajaan Jawa kuno disebutkan dalam berita Cina dari Masa Dinasti Tang (681-906 M). Keadaan fisik kotanya dikelilingi tembok yang terbuat dari papan-papan kayu. Kesibukan senantiasa menjadi keseharian di pintu terluar pagar Kadatwan. Beberapa utusan dari daerah datang berkunjung, mengajukan permohonan, dan mencari solusi penyelesaian masalah. Pupuh 9 Nagarakrtagama menceritakan para penghadap jumlahnya tak terbilang duduk mengantri di tengah keindahan lapang watangan yang luas. Raja tinggal di istana yang terletak di ibu kota kerajaan yang dikelilingi oleh dinding dari bata dan batang-batang kayu (Groeneveldt, 1960). Di dalam istana tinggal keluarga raja yang terdiri dari permaisuri, selir-selir dan anak-anaknya yang belum dewasa dan hamba istana. Sementara itu di luar istana tapi masih di dalam dinding kota terdapat kediaman putra mahkota dan kediaman para pejabat tinggi kerajaan. Mereka mendiami rumah mereka dengan keluarga masing-masing. Rumah-rumah itu terletak di dalam perkampungan khusus yang terdapat di dalam lingkungan tembok kota dan tinggal dengan para hamba mereka (Sumadio, 1984).

Sima atau Wanua adalah lingkungan permukiman desa atau di luar Kadatwan. Setiap Wanua memiliki kekhususunan dalam hal peran dan mata pencaharian dan diwajibkan membayar pajak kepada raja. Ketika Wanua memiliki peran yang signifikan bagi kerajaan, Wanua dapat diangkat menjadi desa $S$ watantra atau desa desa otonom yang bebas pajak dan disebut sebagai Sima. Peran signifikan Wanua beragam, diantaranya jika desa berperan baik sebagai pengelola pelabuhan sungai, membangun dan merawat tanggul, menjaga dan turut aktif menyelenggarakan ritual di tempat suci, serta juga berperan sebagai benteng pertahanan dan/atau membantu penyelamatan raja di tengah peperangan. Pada narasi naskah kuno, disebutkan kondisi lanskap Wanua yang cenderung didominasi fisik alami, jalan berbatu dan berlumut, sawah luas, pantai dengan hamparan batu karang, tebing curam, dan seringkali disebutkan bersebelahan dengan hutan. Pupuh 22 Nagarakrtagama menggambarkan situasi desa Sadeng di pesisir selatan pulau Jawa. Wanua berupa kesatuan komunitas yang di dalamnya terdapat penduduk biasa dan pendeta. Setiap Wanua memiliki keahlian sendiri-sendiri sebagai desa nelayan, petani padi, Wanua pengrajin emas, dan Wanua pandai besi.

Dharma Haji adalah lingkungan suci yang diperuntukkan bagi raja dan keluarganya. Lingkungan suci kerajaan biasa menjadi tempat pendharmaan bagi raja-raja dan keluarga bangwasan yang meninggal. Situs fisik berupa candi monumental dengan relief dinding candi mengandung cerita pengajaran dari kitab-kitab suci agama Hindu, cerita dan pesan moral yang serupa atau dapat diambil dari perjalanan hidup bangsawan yang didharmakan. Selain candi, juga seringkali terdapat danau atau kolam pemandian dan pemandangan alam yang indah. Menurut catatan perjalanan Hayam Wuruk, lingkungan ini juga kerap menjadi tempat peristirahatan bangsawan kerajaan dalam perjalanan ziarah. Nagarakertagama Pupuh 31 menceritakan tentang Kalayu adalah nama desa perdikan Kasogatan, tempat candi makam sanak kadang Baginda raja, dimana penyekaran di makam dilakukan dengan sangat hormat. Keindahan Bureng diceritakan pada Pupuh 38 : "Telaga tergumpal airnya jernih, Kebiru-biruan, di tengahnya terdapat candi karang bermekala, di tepinya terdapat rumah berderet, penuh pelbagai ragam bunga, Tujuan para pelancong penyerap sari kesenangan. Terlewati keindahannya; berganti cerita narpati, Setelah reda terik matahari, melintas tegal tinggi, Rumputnya tebal rata, hijau mengkilat, indah terpandang, Luas terlihat laksana lautan kecil berombak jurang. Seraya berkeliling kereta lari tergesa-gesa."

Dharma Ipas adalah adalah lokasi permukiman yang didirikan di atas tanah yang dihibahkan kepada orang-orang miskin, pendeta Siwa, Buddha dan Rsi. Nagarakertagama pupuh 19 menyebutkan dukuh Kasogatan Madakaripura dengan pemandangan indah, tanahnya anugerah Sri Baginda kepada Gajah Mada, teratur rapi. Di situlah Baginda 
menempati pasanggrahan yang terhias sangat bergas, Sementara mengunjungi mata air, dengan ramah melakukan mandi-bakti. Pupuh 32 menyebutkan: "Sebuah asrama di rimba Sagara, mendaki bukit-bukit ke arah selatan dan melintasi terusan Buluh, Melalui wilayah Gede, sebentar lagi sampai di asrama Sagara, letaknya gaib ajaib di tengah-tengah hutan membangkitkan rasa kagum rindu."

Mandala atau Wanasrama diduga berasal di luar kewenangan ketiga pejabat kerajaan, dan memiliki tingkat kemandirian tinggi sebagai tempat mempelajari ilmu agama Hindu-Buddha dipimpin oleh seorang dewaguru karenanya juga dikenal dengan sebutan kadewaguruan. Di tengah lawatan Hayam Wuruk, Mpu Prapanca memisahkan diri sebagaimana diceritakan Nagarakertagama Pupuh 35: Prapanca memilih tinggal di sebelah barat Pasuruan, menuju asrama Indarbaru yang letaknya di daerah Desa Hujung.

\section{Relasi Antara Karakter dan Aktivitas pada Tiap Tipe Lanskap}

Pada tahap ini penelitian mengelompokkan informasi menurut jenis tipe lingkungan: Kadatwan, Sima/ Wenua, Dharma Haji, Dharma Ipas dan Mandala. Setiap tipe lingkungan memiliki aktivitas utama yang membedakannya dengan tipe-tipe lainnya, demikian pula makna atau kualitas ruang yang dirasakan selama berada di lingkungan tersebut. Berikut ini fitur pembentuk kualitas dan pendukung aktivitas yang dirangkum pada Tabel 1 berikut.

Tabel 1. Fungsi, Makna dan Fitur Pembentuk Ruang Lanskap

\begin{tabular}{|c|c|c|c|}
\hline Tipe Lingkungan & Praktik Budaya & Makna/Kualitas & Fitur Pendukung \\
\hline Kadatwan & $\begin{array}{l}\text { o Memerintah } \\
\text { o Membahas } \\
\text { perpolitikan } \\
\text { O Melaksanakan } \\
\text { upacara } \\
\text { keagamaan dan } \\
\text { perayaan } \\
\text { o Bermukim } \\
\text { o Berperang } \\
\text { o Berdagang strategi } \\
\text { O Belajar peni } \\
\text { perang dan seni } \\
\text { O Berkeliaran } \\
\text { o Berjaga } \\
\text { o Berkumpul }\end{array}$ & 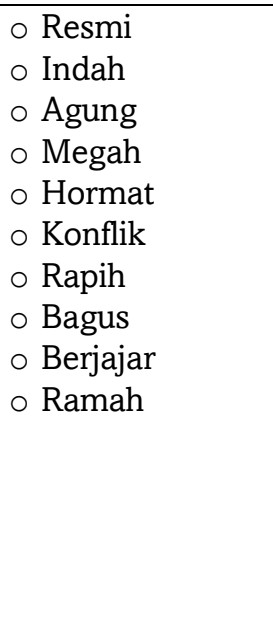 & $\begin{array}{l}\text { o Witana } \\
\text { O Watangan } \\
\text { o Bangsal agung } \\
\text { o Kali } \\
\text { o Petirtaan } \\
\text { o Bangunan berhias kain } \\
\text { o Umbul-umbul } \\
\text { o Candi peringatan } \\
\text { O Taman bunga } \\
\text { o Pelabuhan } \\
\text { o Pasar } \\
\text { o Lapangan luas } \\
\text { o Rumah bangsawan } \\
\text { o Mata air }\end{array}$ \\
\hline Sima/ Wenua & $\begin{array}{l}\text { o Bermukim } \\
\text { o Bertani / berkebun } \\
\text { o Mengembala } \\
\text { ternak } \\
\text { o Menangkap } \\
\text { burung } \\
\text { o Berkarya lainnya } \\
\text { o Berdagang } \\
\text { o Bercengkrama } \\
\text { o Memasak } \\
\text { o Melaksanakan } \\
\text { upacara } \\
\text { keagamaan } \\
\text { o Menyambut } \\
\text { kehadiran raja } \\
\text { o Menikmati } \\
\text { pemandangan }\end{array}$ & $\begin{array}{l}\text { ○ Ramai } \\
\text { ○ Alami } \\
\text { ○ Indah } \\
\text { ○ Licin } \\
\text { ○ Rindang }\end{array}$ & $\begin{array}{l}\text { o Sawah } \\
\text { o Kebun } \\
\text { o Hutan } \\
\text { o Jalan berbatu } \\
\text { o Sungai } \\
\text { o Tebing curam } \\
\text { o Pohon } \\
\text { o Gubuk } \\
\text { o Pantai } \\
\text { o Batu Karang } \\
\text { o Ternak } \\
\text { o Ilalang } \\
\text { o Danau }\end{array}$ \\
\hline
\end{tabular}




\begin{tabular}{llll}
\hline Tipe Lingkungan & Praktik Budaya & Makna/Kualitas & Fitur Pendukung \\
\hline Dharma Haji & $\circ$ Berziarah & $\circ$ Hormat & $\circ$ Pesanggarahan \\
& $\circ$ Berkunjung & $\circ$ Suka cita & $\circ$ Candi \\
& $\circ$ Memeluk & $\circ$ Gairah & $\circ$ Hutan buru \\
& $\circ$ Meriba & $\circ$ Rapih & $\circ$ Taman bunga \\
& $\circ$ Mendaki & $\circ$ Indah & $\circ$ Bukit \\
& $\circ$ Bermenung & $\circ$ Sejuk & $\circ$ Jurang \\
& $\circ$ Berburu & $\circ$ Suci & $\circ$ Kolam \\
& $\circ$ Menjelajah & & $\circ$ Danau \\
& $\circ$ Berpesiar & & $\circ$ Rumah \\
& $\circ$ Menikmati & & $\circ$ Pemandian \\
& pemandangan & & $\circ$ Halaman berpagar \\
& & & $\circ$ Asram \\
& $\circ$ Mengasingkan diri & $\circ$ Rindang/rimbun & $\circ$ Padang alang-alang \\
& $\circ$ Bermukim & $\circ$ Jauh & $\circ$ Asram \\
D Berkunjung & $\circ$ Tidak terurus & $\circ$ Pohon besar \\
& $\circ$ Berziarah & & $\circ$ Pemandian \\
& $\circ$ Bersembunyi & & $\circ$ Hutan \\
& $\circ$ Berkunjung & $\circ$ Suci/Keramat & $\circ$ Batur \\
& $\circ$ Bermukim & $\circ$ Hormat & $\circ$ Asrama \\
& $\circ$ Belajar agama & $\circ$ Gembira & $\circ$ Naskah lontar \\
& $\circ$ Membina & & $\circ$ Candi \\
& $\circ$ Melaksanakan & & $\circ$ Gunung \\
upacara & & $\circ$ Sumber mata air \\
Mandala & & \\
& & \\
& & &
\end{tabular}

Sumber: Hasil analisis

Lingkungan Kadatwan dimanfaatkan untuk aktivitas yang terkait langsung dengan aktivitas penguasa, perpolitikan, dan kegiatan administrasi negara. Sebagaimana disebutkan pada banyak referensi, pada keseharian di lingkungan Kadatwan tetamu silih berganti datang untuk membicarakan kebijakan raja dan persoalan yang muncul di daerah. Disamping itu, terdapat lalu-lalang pasukan kerajaan mengamankan lingkungan. Keluarga bangsawan bermukim di lapis pertama pagar Kadatwan. Anak-anak bangsawan menimba ilmu politik-kebijaksanaan dan kesenian dari para cendikiawan pendeta yang tinggal di lingkungan Kadatwan. Lapangan luas di luar pagar Kadatwan menjadi ruang multifungsi dan terdapat pasar dekat dengan pelabuhan sungai di kejauhan. Secara keseluruhan kualitas yang dihadirkan dalam tatanan lingkungan Kadatwan adalah kemegahan dan kehormatan penguasa melalui bangunan monumental berupa pagar, gapura, wentilan dan bangunan lain yang dihias dengan kain berwarna-warni dan ukiran yang megah pada tiang dan dinding bangunan di Kadatwan. Suasana formal tertata dimanifestasikan oleh tatanan lingkungan permukiman keluarga bangsawan berderet rapih di kanan-kiri ruas jalan dan kali yang lurus dan bersih.

Dharma Haji sebagai tanah yang dianugerahkan kepada pendeta biasa menjadi tempat mendharmakan keluarga raja terdahulu. Lingkungan Dharma Haji juga menjadi tempat bagi keluarga raja berziarah dan menenangkan diri dari urusan politik pemerintahan. Raja datang berziarah sekaligus berburu, menikmati pemandangan alam, dan bersuka-cita dengan wanita setempat di pesanggarahan. Beberapa literatur menyebut adanya Candi Bukur sebagai tempat peristirahatan keluarga raja di dataran tinggi dengan pemandangan alam elok sebagaimana tervisualisasikan pada dinding relief Candi Panataran (Maulidi \& Rukmi, 2018b).

Dharma Ipas dan Mandala adalah dua lingkungan yang terlepas dari urusan duniawi dan situasi perpolitikan. Dharma Ipas adalah tempat pertapaan khususnya bagi penganut 
ajaran Hindu Tantraisme. Mereka mendirikan permukiman kecil di dalam hutan. Kehidupan mereka kadang bergantung juga pada desa sekitar, dari dharma pada masyarakat Wenua sekitar. Lingkungan Dharma Ipas kerap digambarkan tidak terurus terutama yang berlokasi jauh dari Wenua. Sementara itu, Mandala adalah lingkungan pendeta yang secara total memisahkan diri dari lingkungan lain secara mandiri. Mandala menjadi tempat pendidikan ilmu transendental bagi para pendeta, biksu wanita, dan orangorang yang telah lelah dengan duniawi dan bersiap mencari kedamaian di akhir hayat (biasa dari kalangan bangsawan). Lokasi Mandala kerap dekat dengan puncak gunung sebagai lokasi yang jauh sekali dari hiruk pikuk Kadatwan. Karena ditinggali oleh bikuni dan bekas bangsawan, lingkungan Mandala lebih terurus dan rapih menyerupai tatanan lingkungan Kadatwan. Gradasi aktivitas dan kualitas ruang lanskap pada tiap tipe lanskap disajikan pada Gambar 1.
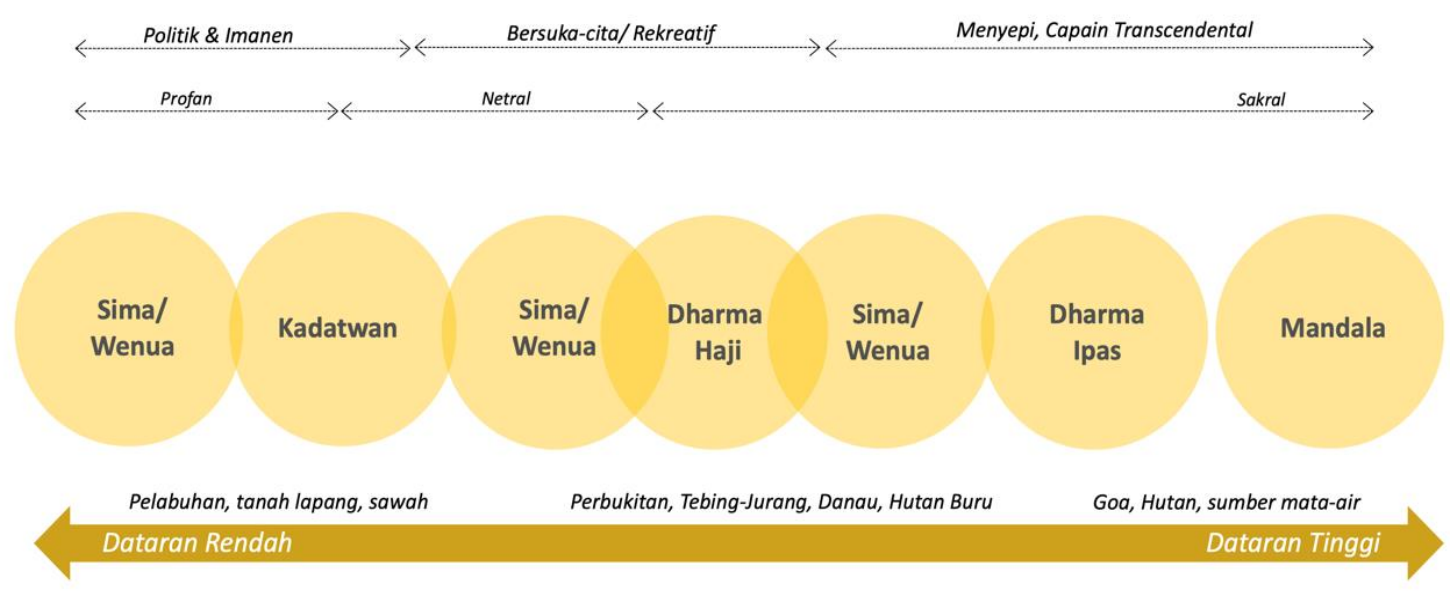

Gambar 1. Karakter dan Kualitas Lingkungan dari Tiap Tipe

Kearifan lokal dalam bentuk hubungan antara bentang lanskap alami dengan budaya yang berkembang di masa Jawa kuno, secara diagramatis ditunjukkan pada Gambar 2. Bentang lanskap alami berupa dataran rendah, perbukitan, dan dataran tinggi membentuk pratik kebudayaan seperti politik kekuasaan, pemerintahan, kegiatan rekreasi, menyepi, mendalami ilmu sprituaal dan sebagainya. Secara simultan praktik kebudayaan tersebut memungkinkan bagi upaya dan kegiatan melestarikan ruang lanskap agar tetap memiliki kualitas khasnya. Upaya dan kegiatan tersebut mewujud dalam bentuk pemanfaatan ruang lanskap, sebagai Kadatwan, Sima / Wenua, Dharma Haji, Dharma Ipas dan Mandala. Dengan hubungan yang terpadu antara lanskap alami dan praktik kebudayaan diperoleh manfaat-manfaat dari ekosistem budaya berupa identitas, pengalaman dan kapabilitas di berbagai aspek, aspek politik, ekonomi dan sosial/spiritual. Keterpaduan antara karakter lanskap alami dengan tipe pemanfaatan ruang, lebih lanjut, diuraikan pada tiga zona ruang lanskap, yakni: Zona Bawah, Zona Tengah, dan Zona Atas.

Zona Bawah, yaitu ruang lanskap alami berupa bentang geografis dataran rendah, dengan kelerengan landai hingga datar. Zona ini dimanfaatkan untuk tipe lingkungan Kadatwan dan Sima/ Wenua dengan praktik budaya dominan terkait dengan pembangunan pusat peradaban kerajaan, perkotaan perdagangan dan pelabuhan. Praktik budaya tersebut memerlukan lanskap yang datar untuk mempermudah transportasi barang dari pelabuhan (pesisir) ke tengah perkotaan. Selain itu, sebagai pusat politik dan kekuasaan lanskap datar akan mempermudahkan mobilisasi pasukan di tengah situasi perang, di mana peperangan 
pada masa Jawa kuno berupa penyerangan langsung ke pusat kerajaan. Kadatwan sebagai pusat kekuasaan kerap diisi dengan bangunan megah seperti wuntilan, pagar atau benteng istana dan lapangan terbuka alun-alun yang memungkinkan pelestarian lanskap alami pada Zona Bawah. Keberpaduan karakter ruang lanskap alami dan praktik budaya memberi manfaat yang memungkinkan untuk membangun pusat kota beridentitas yang mendukung pengalaman ruang monumental di tengah kota.

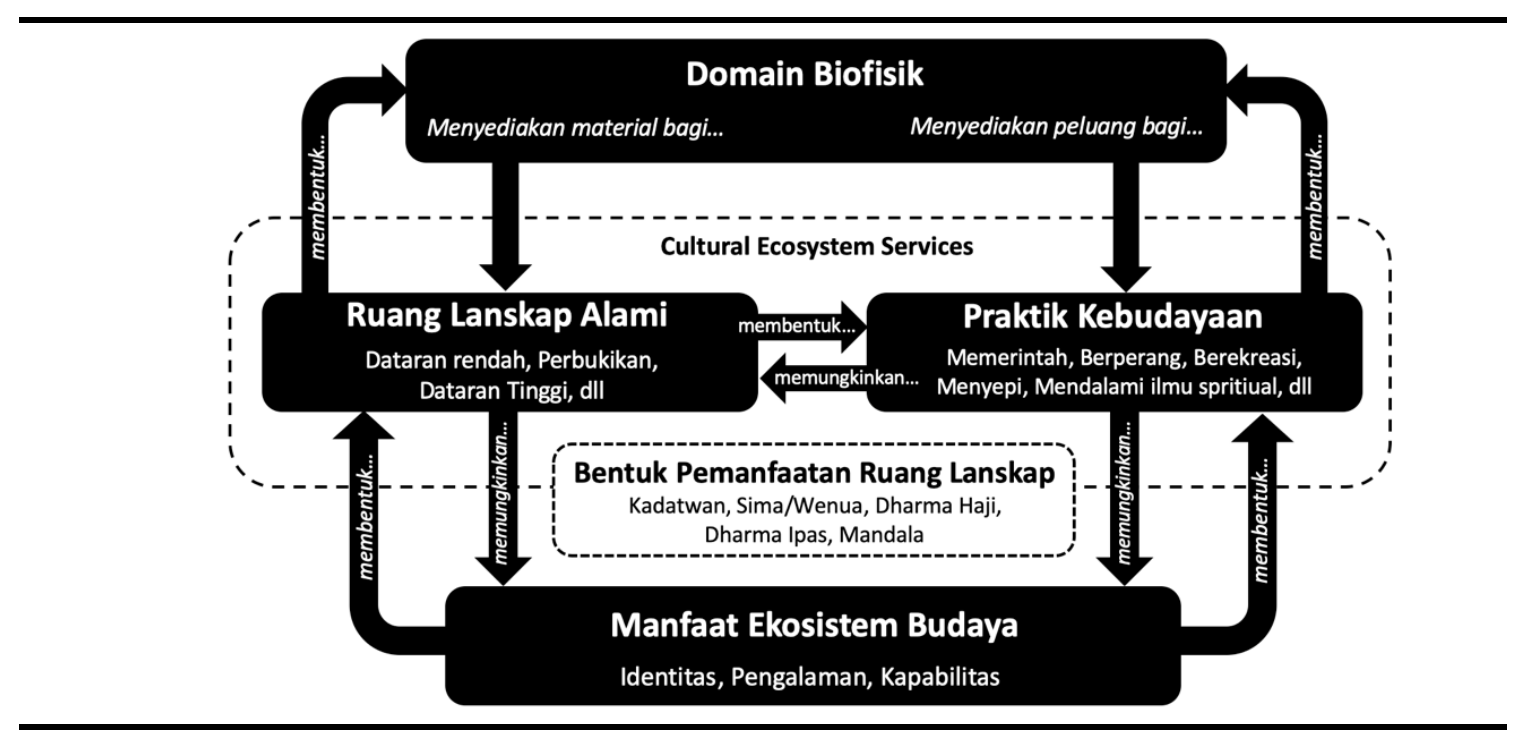

Gambar 2. Model Kearifan Lokal Dalam Kerangka Hubungan Lanskap Alami dan Praktik Kebudayaan Pada Masa Jawa Kuno

Gambar 3. Bentang Alam Dataran Rendah Bekas Kadatwan Majapahit di Trowulan, Mojokerto

Zona Tengah, memiliki karakter berupa perbukitan dengan pemandangan yang indah mendukung aktivitas rekreatif untuk melepaskan diri sejenak dari hiruk-pikuk kehidupan politik di pusat kota. Praktik kebudayaan rekreatif di perbukitan sejalan dengan praktik ziarah. Zona ini terbentuk dari Wenua yang memiliki bentang lanskap mendukung dan kerap menjadi tempat pendharmaan abu jenasah raja-raja sebagai simbol memberikan tempat yang indah bagi arwah sang raja. Praktik ini biasa diringi dengan menaikkan status Wenua menjadi Sima atau Dharma Haji yang bebas pajak namun warga setempat diwajibkan untuk memelihara kelestarian lingkungan dan situs. Hayam Wuruk biasa berziarah sambil menikmati pemandangan indah dan udara sejuk pegunungan di zona ini, sambil menikmati pentas kesenian bersama warga desa sekitar. Sebagai contoh gambaran bentang lanskap di lingkungan Dharma Haji, adalah komplek Candi Jawi di perbukitan dengan latar pemandangan Gunung Penanggungan dan Gunung Welirang di kejauhan. 
Keindahan lanskap danau di komplek Candi Sumber Monte juga kerap dikunjungi oleh Hayam Wuruk di abad ke 15, dimana keindahannya masih dapat dinikmati hingga sekarang (Gambar 3 dan 4)
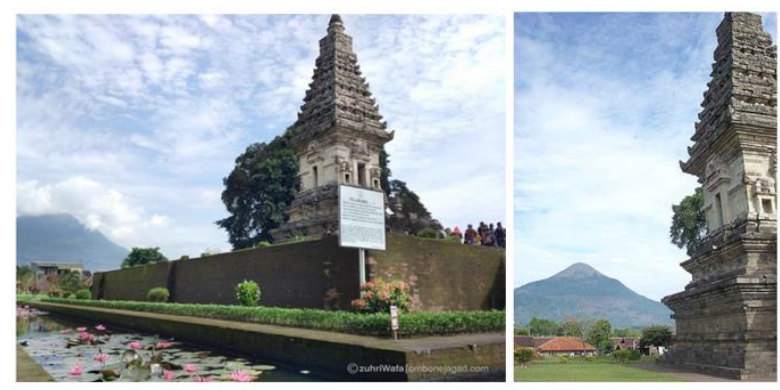

Gambar 4. Keindahan Lanskap Lingkungan Dharma Haji Candi Jawi di

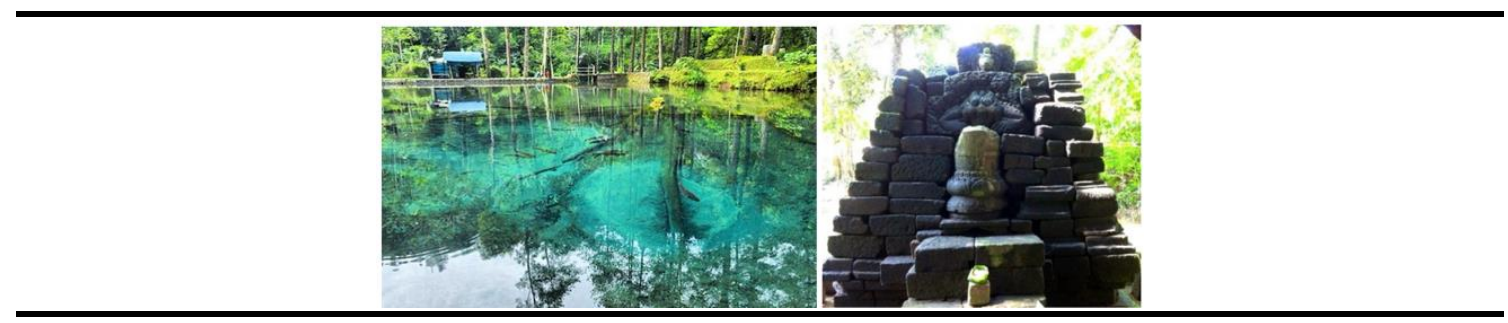

Gambar 5. Komplek Candi Rambut Monte dengan dan Danau Jernih di Tengah Perbukitan Kabupaten Blitar

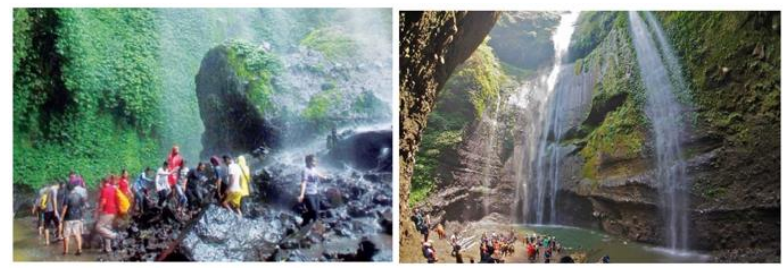

Gambar 6. Situs Madakaripura, Karesian yang dianugerahkan kepada Gajah Mada

Zona Tengah juga menjadi tempat bagi Dharma Ipas, dimana para petapa atau $R s i$ mengasingkan diri untuk mendalami ajaran agama, khususnya Tantraisme yang memang tidak semua orang boleh menjalaninya. Salah satu Dharma Ipas disebutkan dalam Nagarakrtagama sebagai anugerah untuk Gajah Mada untuk memiliki karesian di pedalaman Jawa sebelah timur, yang sekarang dikenal dengan Madakaripura. Terletak di cekungan, aliran sungai dan air terjun indah diapit oleh tebing curam dan sempit, namun keindahan dan aura magis masih dapat dirasakan. Konon Gajah Mada bersemedi di sini setelah bersalah dalam mengobarkan perang Bubat, membunuh seluruh keluarga dan pasukan Raja Sunda yang datang bertamu membawakan calon pengantin untuk Hayam Wuruk. Manfaat ekosistem budaya yang diperoleh dari pemanfaatan lanskap zona tengah sebagai Dharma Haji dan Dharma Ipas, antara lain: legalitas kekuasaan atas daerah di luar Kadatwan; pengalaman rekreatif, mencari inspirasi, lepas dari hiruk-pikuk perkotaan; serta manfaat berupa kesehatan jiwa yang lebih baik dan memperoleh gagasan bijaksana atas masalah kerajaan. 
Zona Atas, kerap dimanfaatkan untuk praktik kebudayaan mengasingkan diri oleh keluarga bangsawan, dengan tinggal di tengah lingkungan Mandala atau Kedewaguruan di bawah kepengurusan biksu dan bikuni terpelajar. Puncak gunung sebagai tempat yang sangat ideal, dengan hamparan lahan yang cukup terbuka dan hutan konifer, bentang pemandangan alam yang terbuka ke cakrawala, namun sunyi, tenang, jauh dari hiruk-pikuk politik dan peperangan yang kerap terjadi di dataran Kadatwan dan Wanua sekitarnya. Bentang lanskap demikian membentuk aktifitas spritual ekslusif karena ia sulit untuk diakses untuk perdagangan dan mobilitas pasukan. Secara simultan praktik kebudayaan tersebut juga memungkinkan bagi lanskap untuk terpelihara tetap alami, dengan lingkungan Mandala yang meenghindari dari aktvitas politik kekuasaan dan perdagangan. Sebagaimana Raja Airlangga memutuskan untuk melepaskan keduniawian di akhir masa tuanya, dengan tinggal di Mandala yang terletak dekat puncak Gunung Semeru. Contoh gambaran lingkungan Kedewaguruan di puncak Gunung Penanggungan Pasuruan dapat dilihat pada Gambar 7.

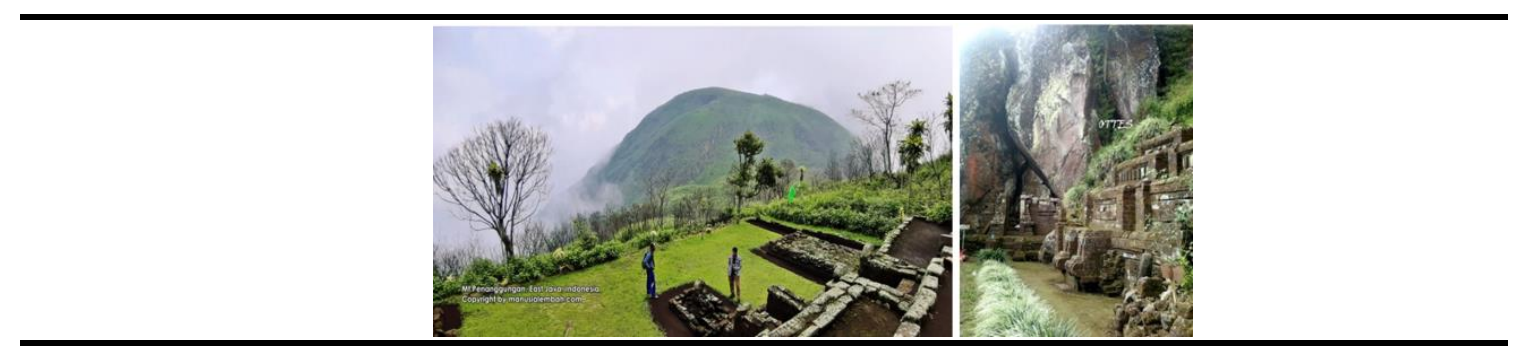

Gambar 7. Situs Kedewaguruan di Puncak Gunung Penaggungan Pasuruan

Berdasarkan pembahasan di atas dapat dipahami bahwa bentang lanskap budaya Jawa kuno di Wilayah DAS Brantas adalah wujud keterpaduan aspek kehidupan yang terjalin keharmonisan antara praktik budaya dan karakter lanksap alami. Hasil analisa menunjukkan bagaimana harmonisasi tercapai dengan menempatkan lokasi tiap tipe lingkungan pada lanskap alami yang dapat mendukung tercapainya kualitas ruang yang sesuai bagi keberlangsungan praktik budaya sekaligus memungkinkan bagi kelestarian lanskap alami. Hubungan tersebut menjadi dasar atau rasionalitas dalam tata ruang wilayah di Daerah Aliran Sungai Kali Brantas sebelum tergantikan oleh rasionalitas kapitalis dalam pembangunan wilayah saat ini.

Teori perkembangan kota dan pembangunan wilayah yang menjadi rujukan pembangunan kontemporer adalah Restructuring Capital dari (Smith, 2013). Mengikuti tren pembangunan wilayah di Amerika tahun 1970-an, teori menjelaskan bahwa perkotaan tumbuh mengikuti aliran kapital dalam mengoperasikan ruang demi mengembangkan profit kapital. Teori tersebut menjadi dasar rasionalitas strategi pembangunan daerah berbasis endogen, bahwa untuk pembangunan ekonomi setiap daerah harus mampu berkomeptisi menarik investasi kapital eksternal masuk ke daerahnya dan dengannya mengembngkan potensi daerah secara lebih ekonomis (Stimson, Stough, \& Roberts, 2006; Vazquez-Barquero, 2002). Sebagai dampak rasionalitas kapitalis tersebut dapat kita jumpai, setiap daerah berkompetisi mengkomodifikasi potensi daerah masing-masing. Pada kasus pembangunan di wilayah DAS Kali Brantas saat ini, dapat dilihat daerah perbukitan Pandaan yang terkategori zona tengah dalam peradaban Jawa kuno (terdapat situs petirtaan dan karesian atau Dharma Ipas), kini terbangun sebagai kawasan industri masif. Demikian pula kawasan industri Mojokerto yang tumbuh ke area dataran tinggi Gunung Penanggungan. Kota Batu terkategori zona atas pada masa Jawa kuno (terdapat situs Kedewaguruan Songgoriti), dengan potensi pemandangan pegunungan dan udara sejuk, kini berkembang sebagai kota pariwisata dengan aneka daya tari wisata buatan. Gedung- 
gedung obyek wisata menggantikan pemandangan alam diikuti pembangunan perumahan menengah ke-atas merubah fungsi lahan hijau menjadi terbangun di lereng perbukitan. Akibat pembangunan daerah yang semata atas dasar rasionalitas pengembangan profit kapital berdampak lebih lanjut terhadap kelestarian alam, bencana banjir dan longsor akibat peningkatan volume run-off, pencemaran air sungai dari limbah indutsri, dan penurunan jumlah sumber mata air (Pemerintah Provinsi Jawa Timur, 2015). Endogenous Development generasi ketiga menyadari isu keberlanjutan ekologi (Vazquez-Barquero, 2002) dengan mengadopsi gagasan Durán (2000) bahwa untuk pembangungan berkelanjutan perlu mempromosikan pembangunan ekonomi, ekologi dan sosial kohesif, melalui penciptaan bisnis kapital yang sejalan dengan pelestarian alam dan budaya. Pendapat ini mengarah kembali kepada keterpaduan praktik budaya ekonomi dengan kelestarian karakter lanskap alami dalam pemanfaatan potensi daerah. Keterpaduan pada lanskap budaya Jawa kuno mungkin memiliki nilai kemanfaatan yang berbeda dengan nilai yang diharapkan masyarakat saat ini, namun tetap layak menjadi satu inspirasi model keterpaduan antara praktik pemanfaatan lahan dengan kelestarian laskap alami dalam pembangunan wilayah kedepan.

\section{KESIMPULAN}

Artikel ini melihat tata ruang kosmologis Jawa dari sudut berbeda, yakni relasinya pemanfaatan lahan dengan karakter lanskap alami wilayah, yang kemudian diterjemahkan sebagai model kearifan lokal dalam tata ruang wilayah. Bentang lanskap alami berupa dataran rendah, perbukitan, dan dataran tinggi membentuk pratik kebudayaan seperti politik kekuasaan, pemerintahan, kegiatan rekreasi, menyepi, mendalami ilmu sprituaal dan sebagainya. Secara simultan praktik kebudayaan tersebut memungkinkan bagi upaya dan kegiatan melestarikan ruang lanskap agar tetap memiliki kualitas uniknya. Upaya dan kegiatan tersebut mewujud dalam bentuk pemanfaatan ruang lanskap, sebagai Kadatwan, Sima/ Wenua, Dharma Haji, Dharma Ipas dan Mandala. Keterpaduan antara lanskap alami dan praktik kebudayaan ini memberi manfaat-manfaat dari ekosistem budaya berupa identitas, pengalaman dan kapabilitas di berbagai aspek, aspek politik, ekonomi dan sosial/spiritual.

Penelitian ini menemukan pola hirarkhis radial dengan Gunung Kawi sebagai porosnya yang merupakan perwujudan kearifan lokal dalam tata ruang lansekap Jawa Kuno. Dalam pola ini, lanskap dibagi menjadi tiga zona, yakni: Zona Bawah, Zona Tengah dan Zona Atas. Zona Bawah adalah lokasi Kadatwan dan Sima / Wenua yang manampung kegiatan bercocok tanam, kegiatan politik dan ekonomi. Zona Tengah merupakan lingkungan Dharma Ipas dan Dharma Haji yang merupakan tempat bagi kegiatan spiritual dan pemulihan diri. Zona Atas adalah lingkungan Mandala yang merupakan lokasi bagi kegiatan pertapaan dan pendalaman agama. Masing-masing zona memiliki memiliki perwujudan karakter yang berbeda dalam hal lingkungan alamiah dan buatan. Kadatwan berlokasi di dataran rendah dengan dominansi lingkungan perkotaan kuno sebagai pusat kerajaan, sementara Mandala di dataran tinggi dengan dominansi lingkungan alamiah. Adanya pembagian hirarki aktivitas dan letak geografis ini bertujuan untuk mengatur pemanfaatan lahan dan kelestarian lingkungan alamiah seperti sumber mata air dan hutan yang memberi manfaat bagi permukiman di dataran rendah. Pola pemanfaatan ruang pada lanskap budaya Jawa kuno ini adalah model keterpaduan antara praktik budaya dan pemanfaatan ruang yang menunjang bagi kelestarian alam.

Pola tatanan dan pemanfaatan ruang lanskap budaya Jawa kuno ini adalah tatanan yang dibangun atas dasar rasionalitas untuk hidup selaras dengan alam. Hal tersebut berbeda dengan rasionalitas teori pembangunan wilayah kotemporer yang didasari rasionalitas kepentingan kapital. Tidak dipungkiri bahwa pembangunan ekonomi adalah 
penting bagi kesejahteraan wilayah, dan juga bukan tidak mungkin peradaban Jawa kuno memperoleh manfaat ekonomis dari tata ruang lanskap budaya Jawa kuno. Oleh karena itu, untuk memperkuat relevansi model kearifan ekosistem lanskap budaya Jawa kuno dengan konteks masa kini, perlu kajian lebih lanjut mengenai bagaimana masyarakat Jawa kuno memperoleh manfaat ekonomi dari tatanan lanskap budaya Jawa kuno.

\section{DAFTAR PUSTAKA}

Atik, D., \& Erdoğan, N. (2017). A model suggestion for determining physical and socio- cultural changes of traditional settlements in Turkey. ITU Journal of The Faculty of Architecture, 14(2), 81-93. https://doi.org/https://doi.org/ 10.5505/itujfa.2017.62534

Casparis, J. G. de. (1956). Selected inscription from 7th to 9th century. Prasasti Indonesia II. Bandung: Masa Baru.

Chan, K., Satterfield, T., \& Goldstein, J. (2012). Rethinking ecosystem services to better address and navigate $\begin{array}{lllll}\text { cultural values. } & \text { Ecological } & \text { Economics, } & 74, & 8-18 .\end{array}$ https://doi.org/https://doi.org/10.1016/j.ecolecon.2011.11.011

Church, A., Fish, R., Ravenscroft, N., \& Stapleton, L. (2015). Cultural ecosystem services, water, and aquatic environments. In Water ecosystem services: A global perspective. Cambridge: Cambridge University Press. Retrieved from https://unesdoc.unesco.org/ark:/48223/pf0000368529

Costanza, R., Groot, R. de, Braat, L., Kubiszewski, I., Fioramonti, L., Sutton, P., ... Grasso, M. (2017). Twenty years of ecosystem services: How far have we come and how far do we still need to go. Ecosystem Services, 28(1), 1-16. https://doi.org/https://doi.org/10.1016/j.ecoser.2017.09.008

Damaika. (2018). Kakawin Nagarakertagama teks asli dan terjemahan: Masa keemasan Majapahit di bawah Prabu Hayam Wuruk dan Mahapatih Gajah Mada. Jakarta: PT Buku Seru.

Durán, G. (2000). La ecologización de las politicas de desarrollo local. Madrid: Universidad Autónoma de Madrid.

Fish, R., Chruch, A., \& Winter, M. (2016). Conceptualising cultural ecosystem services: A novel framework for research and critical engagement. Ecosystem Services, 21(B), 208-217. https://doi.org/10.1016/j.ecoser.2016.09.002

Giannakopoulou, S., Xypolitakou, E., Damigos, D., \& Kaliampakos, D. (2017). How visitors value traditional built environment? Evidence from a contingent valuation survey. Journal of Cultural Heritage, 24, 157164. https://doi.org/https://doi.org/10.1016/j.culher.2016.11.004

Groeneveldt, W. P. (1960). Historical notes on Indonesian and Malaya. Jakarta: CV Bhratara.

Kramrisch, S. (1981). The Hindu temple Volume I. Motilal Banarsidass.

Kumar, A. (2005). Vaastu: The art and science of living. New York: Sterling Publishers.

Maulidi, C., \& Rukmi, W. I. (2018a). Meninjau harmonisasi alam dan fungsi ruang pada bentang lanskap budaya Jawa kuno di lembah kali Brantas. In Prosiding Seminar Nasional Sosiologi Perkotaan. Surakarta: Kekata Publisher.

Maulidi, C., \& Rukmi, W. I. (2018b). Tipologi lanskap Jawa kuno dari ilustrasi relief Candi Jawi, Jago dan Panataran. Jurnal Tata Kota Dan Daerah, 10(2), 107-116. https://doi.org/http://dx.doi.org/10.21776/ub.takoda.2018.010.02.6

Pemerintah Provinsi Jawa Timur. (2015). Status lingkungan hidup daerah (SLDH). Surabaya.

Plieninger, T., \& Bieling, C. (2012). Resilience and the cultural landscape - Understanding and managing change in human-shaped environments. Cambridge University Press. https://doi.org/https://doi.org/10.1017/CBO9781139107778

Pott, P. H. (1966). Yoga and Yantra: Their interpretation and their significance for Indian archaeology. The Hague.

Radzuan, I. S. M., Fukami, N., \& Ahmad, Y. (2015). Incentives for the conservation of traditional settlements: Residents' perception in Ainokura and Kawagoe, Japan. Journal of Tourism and Cultural Change, 13(4), 301-329. https://doi.org/https://doi.org/10.1080/14766825.2014.952302

Rahardjo, S. (2011). Peradaban Jawa dari Mataram kuno sampai Majapahit akhir. Jakarta: Komunitas Bambu.

Sedyawati, E. (1984). Tari: Tinjauan dari berbagai segi. Jakarta: Pustaka Jaya.

Setijanti, P., Defiana, I., Setyawan, W., Silas, J., Firmaningtyas, S., \& Ernawati, R. (2015). Traditional settlement livability in creating sustainable living. Procedia - Social and Behavioral Sciences, 179, 204-211. https://doi.org/https://doi.org/10.1016/j.sbspro.2015.02.423 
Smith, N. (2013). Gentrification, the frontier, and the restructuring of urban space. In N. Smith \& P. Williams (Eds.), Gentrification of the city (pp. 15-35). London: https://doi.org/10.4324/9781315889092.

Stimson, R., Stough, R., \& Roberts, B. (2006). Regional economic development analysis and planning strategy (second edition). Springer.

Sumadio, B. (1984). Sejarah nasional Indonesia. Jilid II. Jakarta: Balai Pustaka.

Vazquez-Barquero, A. (2002). Endogenous development. Networking, innovation, institutions and cities. Routledge. 